\title{
Kadar resistin serum berhubungan dengan Skor child-turcotte pugh pada penderita sirosis hati
}

\author{
Hendra Koncoro', Putu Prathiwi Primadharsini², I Ketut Mariadi², Gde Somayana², \\ I Gusti Agung Suryadarma², Nyoman Purwadi², I Dewa Nyoman Wibawa ${ }^{2}$
}

${ }^{1}$ Departemen Ilmu Penyakit Dalam RS St. Carolus Jakarta

${ }^{2}$ Divisi Gastroenterohepatologi Departemen Ilmu Penyakit Dalam FK Universitas Udayana/ RS

Sanglah Denpasar
Tanggal diterima : 1 Meret 2017 Tanggal Disetujui : 1 Mei 2017 Tanggal Diterbitkan : 10 Mei 2017
Latar Belakang: Sirosis hati (SH) sering disertai tingginya resistensi insulin dan kondisi proinflamasi. Resistin yang merupakan suatu adipokin, diketahui memiliki hubungan dengan resistensi insulin dan inflamasi. Studi-studi resistin pada SH memperlihatkan hasil yang bervariasi. Tujuan penelitian ini adalah untuk mencari hubungan kadar resistin serum dengan skor Child-Turcotte Pugh (CTP) pada penderita SH.

Metode: Penelitian observasional, studi potong lintang ini dilaksanakan di RSUP Sanglah dari September 2014 sampai dengan Juni 2015 dengan menggunakan 75 pasien sirosis hati sebagai sampel. Kriteria inklusi mencakup pasien sirosis hati tanpa memandang etiologinya dan berusia 12 tahun atau lebih. Variabel yang diperiksa pada penelitian ini yaitu skor CTP (kadar albumin serum, kadar bilirubin total serum, nilai waktu protrombin, kadar international normalized ratio (INR), tanda ascites, tanda ensefalopati hepatikum), kadar (-reactive protein (CRP), dan kadar resistin serum.

Hasil: Enam puluh lima persen dari 75 sampel adalah laki-laki dan sisanya perempuan. Sebelas diantaranya (14,7\%) adalah kelas CTP A, 31 (41,3\%) kelas CTP B, dan 33 (44\%) kelas CTP C. Rerata kadar CRP adalah 15,05 \pm 15,86 mg/L. Rerata kadar resistin adalah $23,39 \pm 17,79 \mathrm{ng} / \mathrm{mL}$. Hasil uji korelasi didapatkan korelasi positif yang sedang antara kadar resistin dan skor CTP $(r=0,438 ; p<0,001)$. Korelasi positif sedang juga didapatkan antara CRP dan resistin $(r=$ $0,478 ; p<0,001)$.

Simpulan: Kadar resistin memiliki korelasi sedang dengan skor CTP pada pasien SH. Kadar resistin didapatkan lebih tinggi kadarnya pada SH yang berat. Hal ini menunjukkan adanya kondisi inflamasi dan resistensi insulin seiring dengan peningkatan derajat beratnya SH.

Kata Kunci. Sirosis hati, resistin, resistensi insulin

Background: Liver cirrhosis (LC) is a disorder characterized by increased insulin resistance and proinflammatory condition. Resistin is an adipokine which known to be related to insulin resistance and inflammation. Studies on resistin in $\mathrm{LC}$ showed various results. This study aimed to determine the correlation between serum resistin levels and ChildTurcotte Pugh (CTP) score in LC.

Methods: This observational, cross-sectional study was conducted in Sanglah Hospital from September 2014 until June 2015 by recruiting $75 \mathrm{LC}$ patients as samples. Inclusion criteria was LC patients despite its etiology and aged more than 12 years old. Variables measured in this study were CTP score (serum albumin levels, serum total bilirubin levels, prothrombin time, international normalized ratio (INR) levels, signs of ascites, signs of hepatic encephalopathy), C-reactive protein (CRP) levels, and serum resistin levels.

Results: Sixty five percent out of 75 samples was male and the rest was female. Eleven of them (14.7\%) were CTP A class, 31 (41.3\%) CTP B class, and 33 (44\%) CTP ( class. Mean CRP levels was 15,05 $\pm 15,86 \mathrm{mg} / \mathrm{L}$. Mean resistin levels was $23,39 \pm 17,79 \mathrm{ng} / \mathrm{mL}$. Correlation test results showed moderate positive correlation between resistin levels and CTP score $(r=0,438 ; p<0,001)$. Moderate positive correlation also found between CRP and resistin $(r=0,478 ; p<0,001)$. Conclusion: Resistin levels has moderate correlation with CTP score in LC. Resistin levels is higher in severe LC. This condition showed inflammation condition and insulin resistance increased as increment of $L C$ severity.

Keywords: Liver cirrhosis, resistin, insulin resistance

\section{PENDAHULUAN}

SH adalah suatu keadaan patologis yang menggambarkan stadium akhir fibrosis hati yang berlangsung progresif yang ditandai dengan distorsi dari arsitektur hepar dan pembentukan nodulus regeneratif.' Kelainan ini merupakan kelainan yang berhubungan dengan banyak organ dan mediator, tidak hanya organ hati. Salah satu mediator adalah dengan resistin. Dalam beberapa tahun terakhir, terdapat berbagai perbedaan pendapat mengenai hubungan antara tingkat keparahan SH dengan kadar resistin serum. Beberapa penelitian menunjukkan bahwa keduanya tidak berhubungan, sementara penelitian lain menunjukkan adanya korelasi positif.

Komplikasi yang sangat kompleks tersebut menyebabkan prognosis $\mathrm{SH}$ sangat bervariasi. Keparahan serta prognosis $\mathrm{SH}$ dapat diprediksi dengan beberapa sistem skoring, antara lain skor Child-Turcotte Pugh (CTP) dan 
skor Model for End Stage Liver Disease (MELD). Skor CTP distratifikasi berdasarkan pemeriksaan objektif dan subjektif terhadap adanya asites, ensefalopati hepatik, kadar bilirubin, kadar albumin dan masa protrombin. ${ }^{2}$

Sirosis hati merupakan penyakit yang memiliki gambaran berupa tingginya resistensi insulin dan kondisi proinflamasi. ${ }^{3,4}$ Hampir semua pasien SH (96\%) mengalami resistensi insulin, dimana $60-80 \%$ terjadi intoleransi glukosa, dan $20-30 \%$ berkembang menjadi diabetes melitus (DM). ${ }^{5}$ DM yang berkembang sebagai komplikasi SH dikenal sebagai hepatogenous diabetes $(H D) .{ }^{6}$ Kondisi proinflamasi yang terjadi pada SH dibuktikan dengan terjadinya peningkatan berbagai sitokin sebagai respon inflamasi. Hal ini terjadi sebagai respon terhadap perlukaan pada hati, baik akibat infeksi virus maupun penyebab non virus seperti obat-obatan, alkohol, toksin, maupun metabolik. Interaksi sitokin dan berbagai tipe sel di hati akan memicu fibrogenesis yang akan memperburuk perjalanan penyakit SH itu sendiri.?

Dewasa ini diketahui bahwa jaringan adiposa memproduksi berbagai peptida yang disebut adipokin. ${ }^{8}$ Adipokin bekerja secara lokal, sentral, dan perifer. ${ }^{9}$ Contoh adipokin antara lain sitokin pro inflamasi seperti tumor necrosis factor- $\alpha$ (TNF $\alpha$ ), interleukin-6 (IL-6), hormon yang terlibat dalam metabolisme seperti adiponektin dan leptin, dan hormon yang terlibat dalam inflamasi serta resistensi insulin seperti resistin. ${ }^{10}$

Resistin termasuk dalam keluarga protein kaya sistein juga dikenal sebagai adipose tissue specific secretory factor (ADSF) atau protein yang ditemukan pada area inflamasi (found in inflammatory zones $=$ FIZZ). Protein ini merupakan suatu adipokin baru dari jaringan adiposa yang berhubungan dengan resistensi insulin dan obesitas pada tikus. ${ }^{11,12}$

Studi yang telah dilakukan sejauh ini menunjukkan pengaruh resistin pada regulasi massa jaringan adiposa, homeostasis glukosa (terutama resistensi insulin), dan inflamasi. ${ }^{13}$ Kadar resistin didapatkan meningkat pada pasien $\mathrm{SH} .{ }^{14}$ Hanya ada sedikit data dalam literatur mengenai hubungan antara SH dengan resistin. ${ }^{15,16,17}$ Kakizaki dkk. (2008) dan Yagmur dkk. (2006) mendapatkan bahwa kadar resistin serum memiliki korelasi dengan beratnya derajat $\mathrm{SH}$ yang digambarkan oleh skor CTP..$^{16,17}$ Sebaliknya, Bahr dkk. pada tahun 2006 melaporkan bahwa tidak ada korelasi antara beratnya derajat $\mathrm{SH}$ dengan kadar resistin serum. ${ }^{15}$

Penelitian yang ada tidak melibatkan ras penduduk Indonesia yang memiliki karakteristik berbeda dengan ras Kaukasia dalam hal antropometri dan etiologi SH, sehingga sukar diekstrapolasikan pada populasi SH di Indonesia. Selain itu, peningkatan kadar resistin serum seiring dengan bertambahnya skor CTP diharapkan dapat menjelaskan gangguan toleransi glukosa dan kondisi proinflamasi pada pasien SH. Dengan memahami peran resistin pada SH sangatlah penting untuk membantu menemukan modalitas terapi baru yang menurunkan kadar adipokin ini sehingga dapat mencegah resistensi insulin dan perburukan pada SH. Dengan mengingat adanya perbedaan hasil penelitian dan populasi dengan penelitian sebelumnya, diperlukan penelitian untuk menilai korelasi antara kadar resistin penderita $\mathrm{SH}$ dengan skor CTP. Tujuan penelitian ini adalah untuk mencari hubungan dan korelasi antara kadar resistin serum dengan skor CTP pada penderita SH

\section{METODE}

Penelitian ini merupakan penelitian korelasi dengan rancangan potong lintang analitik (analytic cross-sectional study) untuk mengetahui apakah kadar resistin serum berhubungan dengan skor CTP pada penderita SH. Penelitian dilakukan di Rumah Sakit Sanglah Denpasar pada bulan Agustus 2014 sampai Juli 2015 dengan pemeriksaan kadar resistin dilakukan di Laboratorium Klinik Prodia, Denpasar. Sebagai kriteria inklusi adalah pasien SH berusia 12 tahun atau lebih baik pria maupun wanita dan bersedia ikut serta dengan menandatangani informed consent. Kriteria eksklusi antara lain pasien SH dengan PGK stadium III-V, infeksi yang ditentukan dengan kadar CRP $>55.8 \mathrm{mg} / \mathrm{L}^{18}$, hipertensi, penyakit jantung koroner, hipertiroid, keganasan, DM, dan sedang memakai obat-obatan anti diabetik, insulin, kortikosteroid, dan golongan statin dalam waktu dua minggu terakhir.

Perkiraan besar sampel untuk penelitian korelasi didapatkan besar sampel adalah sebanyak 75 orang, dengan tingkat kesalahan tipe I ditetapkan 5\% dan tingkat kesalahan tipe II ditetapkan 20\%. Variabel bebas (independent variabel) pada penelitian ini adalah skor Child-Turcotte Pugh, sedangkan variabel tergantung (dependent variabel) adalah kadar resistin serum. Adapun variabel kendali adalah umur, jenis kelamin, indeks massa tubuh, dan kadar CRP serum. Pengambilan sampel dilakukan secara consecutive sampling terhadap semua pasien SH. Subyek yang memenuhi kriteria kemudian dilakukan anamnesis, pemeriksaan fisik, dan pemeriksaan kadar CRP. Pemeriksaan kadar CRP akan dilakukan di laboratorium klinik RSUP Sanglah Denpasar. Pasien juga dilakukan pengambilan darah untuk pemeriksaan kadar resistin serum di Laboratorium Klinik Prodia, Denpasar. Kadar CRP serum diukur dengan menggunakan metode imunoturbidimetri. Kadar resistin serum diukur dengan menggunakan metode enzyme-linked immunosorbent assay (ELISA).

Uji deskriptif, dilakukan untuk memperoleh karakteristik subyek penelitian. Sebelum menganalisis hubungan antar variabel terlebih dahulu dilakukan uji normalitas dengan menggunakan uji Kolmogorov-Smirnov. Karena data berdistribusi tidak normal, dilakukan transformasi data. Setelah transformasi data, didapatkan distribusi normal 
sehingga dilakukan uji parametrik. Untuk menilai korelasi resistin dengan skor CTP digunakan uji korelasi Pearson. Uji regresi multipel untuk menilai besarnya pengaruh variabel kendali terhadap resistin. Analisis data dilakukan dengan bantuan perangkat komputer. Nilai $p$ dianggap bermakna apabila $\mathrm{p}<0,05$.

\section{HASIL}

Dalam penelitian ini diikutkan 75 pasien SH di RSUP Sanglah Denpasar sebagai sampel, yang telah memenuhi kriteria inklusi dan tidak terkena kriteria eksklusi. Dari 75 sampel didapatkan 49 orang $(65,3 \%)$ laki-laki dan 26 orang $(34,7 \%)$ perempuan. Berdasarkan etiologi SH didapatkan bahwa HBsAg positif pada 53,33\% pasien dan anti $\mathrm{HCV}$ positif pada $18,67 \%$ pasien, sedangkan $28 \%$ pasien tidak ditemukan HBsAg maupun anti HCV positif. Usia termuda adalah 14 tahun dan tertua adalah 79 tahun, dengan rerata 53,21 $\pm 14,47$ tahun. Sebagian besar sampel yang ikut dalam penelitian ini $(85,3 \%)$ mengalami derajat kerusakan hati sedang-berat (CTP B dan C) dan hanya $11(14,7 \%)$ pasien yang memiliki derajat kerusakan hati yang ringan (CTP A). Karakteristik dari sampel yang ikut dalam penelitian ini secara lengkap dapat dilihat pada Tabel 1.

Sebelum dilakukan uji statistik, terlebih dahulu dilakukan uji normalitas dengan analisis Kolmogorov-Smirnov. Uji normalitas untuk skor CTP didapatkan nilai $p=0,092$. Nilai $p>0,05$ berarti sebaran data normal. Sedangkan uji normalitas untuk resistin didapatkan nilai $p<0,001$. Nilai $p<0,05$ berarti sebaran data tidak normal. Oleh karena sebaran data tidak normal, langkah selanjutnya adalah melakukan transformasi data kadar resistin dengan fungsi logaritma. Setelah dilakukan transformasi data, hasil resistin menjadi berdistribusi normal dengan $p=0.059$, sehingga dilakukan analisis parametrik.

Dari pemeriksaan resistin didapatkan nilai minimum $3,97 \mathrm{ng} / \mathrm{mL}$ dan maksimum $69,63 \mathrm{ng} / \mathrm{mL}$, dengan rerata 23,39 $\pm 17,79 \mathrm{ng} / \mathrm{mL}$. Penderita kelompok CTP A memiliki rerata resistin 12,67 $\pm 6,04 \mathrm{ng} / \mathrm{mL}$, kelompok CTP B memiliki rerata resistin serum 18,05 $\pm 14,58 \mathrm{ng} / \mathrm{mL}$, dan kelompok CTP C memiliki rerata resistin serum 31,98 $\pm 19,44 \mathrm{ng} / \mathrm{mL}$. Terdapat kecenderungan peningkatan resistin serum pada derajat $\mathrm{SH}$ (kelas CTP) yang bertambah berat (Gambar 1).

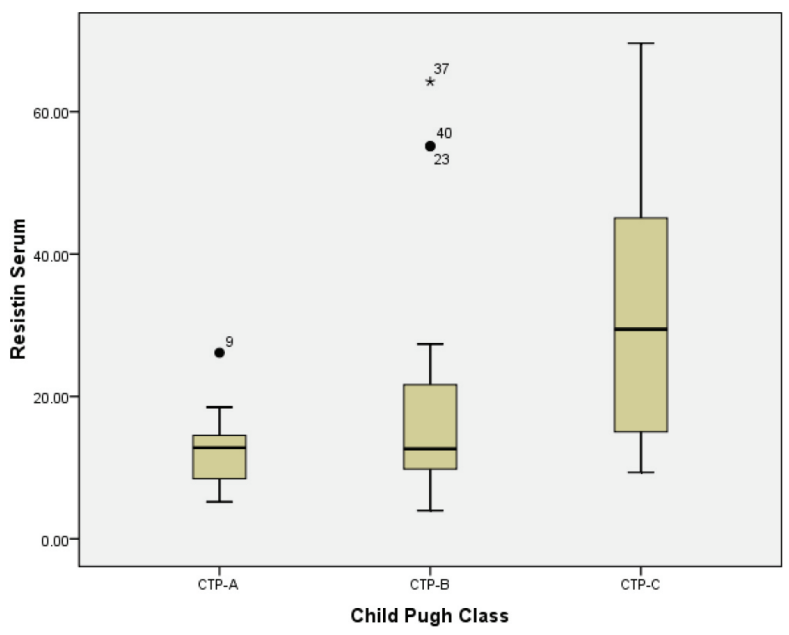

Gambar 1. Kadar rerata resistin pada masing-masing kelas CTP

Tabel 1. Karakteristik Dasar Sampel

\begin{tabular}{lccc}
\hline \multicolumn{1}{c}{ Variabel } & CTP A & CTP B & CTP C \\
\hline Jumlah, n (\%) & $11(14,7)$ & $31(41,3)$ & $33(44)$ \\
Umur (tahun), rerata \pm SB & $54 \pm 16,08$ & $54,13 \pm 11,41$ & $51,91 \pm 15,62$ \\
Albumin (mg/dL), rerata \pm SB & $3,55 \pm 0,50$ & $2,82 \pm 0,64$ & $2,43 \pm 0,60$ \\
Bilirubin (mg/dL), median (minimum-maksimum) & $0,59(0,28-1,90)$ & $1,57(0,36-4,83)$ & $5,95(0,98-21,99)$ \\
INR, median (minimum-maksimum) & $1,31(0,97-1,65)$ & $1,48(0,94-2,46)$ & $2,01(0,96-3,97)$ \\
Ascites, n (\%) & $2(18,2)$ & $13(41,9)$ & $23(69,7)$ \\
Ensefalopati hepatic, n (\%) & $0(0)$ & $3(9,7)$ & $11(33,3)$ \\
SC (mg/dL), median (minimum-maksimum) & $0,78(0,67-1,30)$ & $0,86(0,49-2,65)$ & $1,11(0,32-2,91)$ \\
Na (mmol/L), median (minimum-maksimum) & $137,23(132-145)$ & $135,5(118,1-152)$ & $132,03(108-144)$ \\
CRP (mg/L), median (minimum-maksimum) & $0,75(0,00-9,80)$ & $7,30(0,02-54,80)$ & $16,00(0,90-51,30)$ \\
Resistin (ng/mL), median (minimum-maksimum) & $12,80(5,18-26,14)$ & $12,63(3,97-64,23)$ & $29,44(9,34-69,63)$
\end{tabular}

INR: International Normalized Ratio, SC: serum creatinine, CRP: C-reactive protein 
Dari uji Post Hoc didapat perbedaan tidak bermakna resistin CTP A dengan CTP B $(p=0,431)$, CTP A dengan CTP C didapatkan perbedaan yang bermakna $(p=0,01)$ dan CTP B dengan CTP C didapatkan perbedaan yang bermakna ( $p=$ $0,001)$. Rerata resistin untuk masing-masing kelas CTP dapat dilihat pada Tabel 2.

Tabel 2. Rerata Kadar Resistin Berdasarkan Kelas CTP

\begin{tabular}{cccccc}
\hline CTP & N & $\begin{array}{c}\text { Median Resistin } \\
\text { (minimum-maksimum) }\end{array}$ & $\begin{array}{c}\text { Rerata } \\
\text { Resistin } \pm \text { SB }\end{array}$ & $p$ \\
\hline A & 11 & $12,80(5,18-26,14)$ & $12,67 \pm 6,04$ & $<0,001$ \\
B & 31 & $12,63(3,97-64,23)$ & $18,05 \pm 14,58$ & \\
C & 33 & $29,44(9,34-69,63)$ & $31,98 \pm 19,44$ & \\
\hline
\end{tabular}

Karena data hasil transformasi memiliki sebaran normal, maka untuk melihat korelasi antara resistin dan skor CTP kemudian dilakukan uji korelasi Pearson. Dengan uji korelasi Pearson didapatkan korelasi positif bermakna antara resistin dan skor CTP dengan $r=0,462 ; p<0,001$. Grafik scatter dari korelasi antara log resistin dan skor CTP dapat dilihat pada gambar 2. Nilai koefisien korelasi 0,462 menunjukkan adanya korelasi sedang yang bermakna antara resistin dan skor CTP.

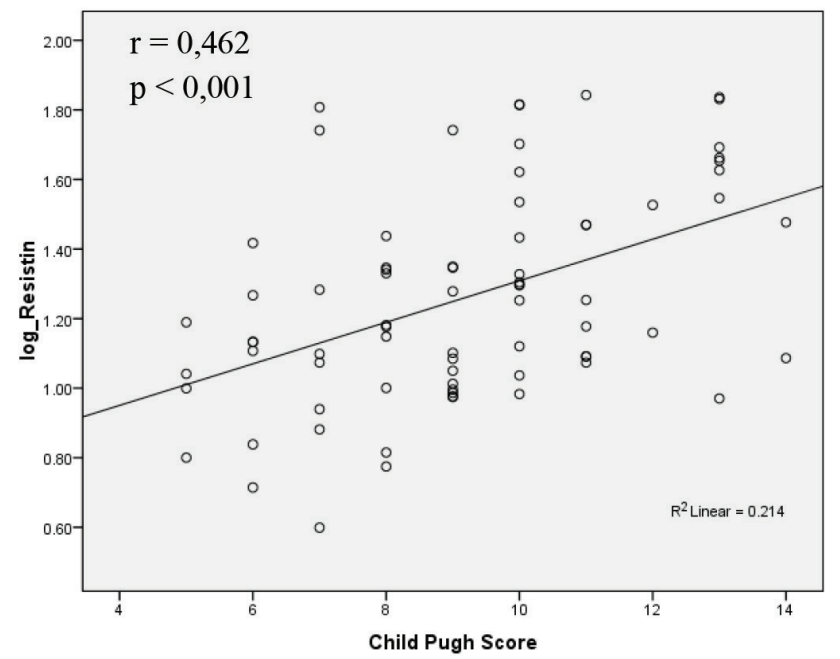

Gambar 2. Korelasi antara resistin dan skor CTP pada SH

Untuk mengetahui model hubungan skor CTP dalam memproduksi kadar resistin maka dilakukan uji regresi linier. Dari uji regresi linier didapatkan formula sebagai berikut: kadar resistin $=(3,146 \mathrm{x}$ skor CTP $)-5,559$. Gambar 2 juga menunjukkan hubungan antara resistin dan skor CTP, dimana pada gambar tersebut tampak hubungan yang sedang antara resistin dan skor CTP, dan hampir $21 \%$ nilai dari resistin ditentukan oleh skor CTP.

Untuk melihat apakah ada variabel lain yang berpengaruh terhadap resistin selain skor CTP, dilakukan analisis multivariat. Variabel-variabel yang diperkirakan memiliki pengaruh antara lain adalah usia, jenis kelamin, indeks massa tubuh, dan kadar CRP. Sebelum dilakukan analisis multivariat, terlebih dahulu dilakukan analisis bivariat untuk mengetahui variabel yang berkorelasi bermakna dengan resistin. Variabel yang memiliki korelasi yang bermakna dengan resistin kemudian dilakukan uji multivariat.

Beberapa kondisi yang berpengaruh terhadap resistin antara lain adalah usia, jenis kelamin, indeks massa tubuh, dan kadar CRP. Variabel usia, indeks massa tubuh, dan kadar CRP diuji dengan uji Spearman. Hubungan antara jenis kelamin dan kadar resistin dinilai dengan uji beda rerata, yaitu uji Mann-Whitney karena tidak berdistribusi normal. Ditemukan korelasi bermakna antara kadar CRP dengan kadar resistin serum $(r=0,478, p<0,001)$. Hubungan antara variabel independen dengan kadar resistin dapat dilihat pada Tabel 3.

Tabel 3. Hubungan Variabel Independen dengan Kadar Resistin

\begin{tabular}{ccc}
\hline Variabel & $\mathrm{r}$ & Nilai $p$ \\
\hline Umur & 0,097 & $0,407^{*}$ \\
Jenis kelamin & - & $0,802^{* *}$ \\
Indeks massa tubuh & 0,101 & $0,386^{*}$ \\
Kadar CRP & 0,478 & $<0,001^{*}$ \\
\hline
\end{tabular}

*Uji Spearman, **uji Mann-Whitney. CRP: C-reactive protein

Dari analisis bivariat, hanya didapatkan skor CTP dan kadar CRP serum yang berhubungan dengan kadar resistin serum. Untuk melihat besarnya pengaruh CRP maka dilakukan analisis multivariat dengan regresi linier multipel. Pada model dengan memasukkan skor CTP dan CRP sebagai variabel independen terhadap kadar resistin sebagai variabel dependen didapatkan bahwa skor CTP dan CRP berpengaruh terhadap kadar resistin dengan $p$ masing-masing adalah 0,027 , dan 0,001 (Tabel 4).

Tabel 4. Hasil Analisis Multivariat Regresi Linier

\begin{tabular}{cccc}
\hline Variabel & Koefisien & $\begin{array}{c}\text { Koefisien } \\
\text { korelasi }\end{array}$ & $\mathrm{P}$ \\
\hline Konstanta & $-5,385$ & & 0,472 \\
CRP serum & 0,271 & 0,242 & 0,027 \\
Skor CTP & 2,684 & 0,354 & 0,001 \\
\hline
\end{tabular}

Dari uji regresi linier multipel didapatkan formula sebagai berikut: kadar resistin $=(0,271 \times \mathrm{CRP})+(2,684 \mathrm{x}$ 
skor CTP) - 5,385. Kualitas persamaan hasil analisis regresi linier dapat dinilai dengan melihat hasil uji ANOVA dan nilai koefisien determinasi. Suatu persamaan dikatakan layak untuk digunakan bila nilai $p$ pada uji $A N O V A<0,05$. Pada uji $A N O V A$ ini, nilai $p$ adalah sebesar $<0,001$. Dengan demikian, rumus yang digunakan layak untuk diaplikasikan.

Tabel 5. Koefisien Korelasi dan Determinasi Model Regresi Variabel yang Berkorelasi dengan Resistin

\begin{tabular}{ccc}
\hline Model Prediktor & $\begin{array}{c}\text { Koefisien } \\
\text { korelasi }\end{array}$ & $\begin{array}{c}\text { Koefisien } \\
\text { determinasi }\end{array}$ \\
\hline CRP, skor CTP & 0,477 & 0,206 \\
\hline
\end{tabular}

Pada model regresi di atas, nilai korelasi adalah 0,477. Nilai ini dapat diinterpretasikan bahwa hubungan kedua variabel penelitian ada di kategori sedang. Melalui Tabel 5 ini juga diperoleh nilai adjusted $R$ square atau koefisien determinasi yang menunjukkan seberapa bagus model regresi yang dibentuk oleh interaksi variabel terikat. Nilai koefisien determinasi yang diperoleh adalah 20,6\% yang dapat ditafsirkan bahwa CRP dan skor CTP memiliki pengaruh kontribusi sebesar 20,6\% terhadap kadar resistin dan 79,4\% lainnya dipengaruhi oleh faktor-faktor lain di luar kadar CRP dan skor CTP.

\section{DISKUSI}

Penelitian ini melibatkan 75 orang penderita $\mathrm{SH}$ dewasa. Sampel terbanyak adalah laki-laki sebanyak 50 orang (66.7\%) dan sisanya 25 orang adalah perempuan. Banyaknya laki-laki pada penelitian ini menunjukkan bahwa SH lebih banyak terjadi pada laki-laki. Salah satu penyebab banyaknya SH pada laki-laki adalah kemampuan bersihan virus yang lebih baik pada wanita, terutama virus hepatitis C. Penelitian yang dilakukan oleh Kenny-Walsh dkk. (1999) menyebutkan bahwa wanita usia muda memiliki kemampuan bersihan virus hepatitis $\mathrm{C}$ lebih tinggi. Tujuh belas tahun setelah paparan virus hepatitis C terhadap 704 wanita muda Irlandia, hanya 390 orang (55\%) yang terdeteksi HCV RNA-nya. Sekitar 45\% sisanya didapatkan antibodi HCV positif, namun tidak dijumpai viremia. ${ }^{19}$ Penelitian yang dilakukan oleh Somia dkk. (2004) mendapatkan rasio antara laki-laki dan perempuan adalah sebesar 2,06: $1 .^{20}$ Di RS Koja, Jakarta dijumpai penderita laki-laki 62.5\%. ${ }^{21}$ Dibandingkan dengan hasil penelitian tersebut di atas, hasil penelitian ini mirip dengan keempat peneliti sebelumnya.

Berdasarkan etiologi, didapatkan HBsAg positif pada $53,33 \%$ pasien dan anti HCV positif pada $18,67 \%$, sedangkan 28\% pasien HBsAg maupun anti HCVnya negatif. Penelitian di Indonesia menyebutkan hepatitis B menyebabkan $\mathrm{SH}$ sebesar 40-50\% dan hepatitis C 30-40\%, sedangkan 10$20 \%$ penyebabnya tidak diketahui. ${ }^{2}$ Indonesia adalah negara endemis infeksi hepatitis B dan C. Walaupun pada penelitian ini, lebih dari seperempat pasien SH tidak berhasil diidentifikasi etiologinya, hepatitis B kronis masih perlu dipikirkan lebih besar daripada yang sudah dapat diketahui saat ini. Hal ini disebabkan karena tidak semua sampel penelitian dilakukan pemeriksaan antiHBc.

Dilihat dari derajat penyakitnya, 11 orang $(14,7 \%)$ tergolong kelas CTP A, 31 (41,3\%) kelas CTP B, dan 33 (44\%) kelas CTP C. Ini berarti penderita SH yang datang berobat sebagian besar dengan derajat penyakit sedang dan berat dimana sudah ada dekompensasi. Dari kepustakaan disebutkan bahwa SH sering merupakan silent disease dimana sebagian besar penderita tetap asimptomatis hingga munculnya tandatanda dekompensasi. Tanda-tanda dekompensasi ini lebih banyak muncul pada penderita $\mathrm{SH}$ dengan derajat penyakit sedang dan berat. ${ }^{22}$

Pada penelitian ini didapatkan konsentrasi resistin yang semakin tinggi seiring dengan semakin beratnya derajat kerusakan hati. Dari pemeriksaan kadar resistin serum, terdapat perbedaan kadar resistin serum antara kelas CTP A dengan CTP C dan CTP B dengan CTP C, namun tidak diikuti oleh kelas CTP A dengan CTP B.

Hasil ini serupa dengan penelitian yang dilakukan oleh Bahr (2006), dimana pasien pada tahapan awal SH telah menunjukkan peningkatan kadar resistin serum, namun tidak didapatkan perbedaan antara kelas CTP A dan CTP B. Sedangkan pada pasien dengan kelas CTP C terdapat perbedaan yang signifikan. ${ }^{15}$

Hasil ini menunjukkan bahwa kadar resistin serum meningkat seiring dengan peningkatan kelas CTP. Adanya proses inflamasi yang lebih berat pada pasien $\mathrm{SH}$ yang mengalami disfungsi hati berat mendukung pernyataan ini. Hal ini sesuai dengan kepustakaan yang menyebutkan adanya peningkatan risiko untuk mengalami infeksi bakteri, berkaitan dengan beratnya derajat gangguan fungsi hati, semakin berat derajat sirosis semakin tinggi risiko untuk mendapatkan infeksi. Risiko ini muncul karena adanya kelainan pada mekanisme pertahanan tubuh, yang meningkatkan risiko untuk infeksi, seperti kekurangan aktivitas bakterisidal dan opsonisasi, gangguan fungsi monosit, penekanan aktivitas fagosit dari sistem RES, kekurangan kemotaksis, dan rendahnya komplemen di serum.

Peningkatan resistin juga menunjukkan resistensi insulin yang lebih berat pada pasien SH kelas CTP C. Peningkatan kadar resistin ini menurut kepustakaan tidak disebabkan karena berkurangnya bersihan hepatik yang semakin berkurang pada disfungsi hati berat, melainkan dapat disebabkan karena respon pelepasan oleh makrofag jaringan akibat kondisi inflamasi dan resistensi insulin. ${ }^{15}$ 
Resistin merupakan peptida kaya sistein dengan berat molekul $12.5 \mathrm{kDa}$ yang berpengaruh terhadap inflamasi dan resistensi insulin. Hasil penelitian ini didapatkan korelasi positif sedang $(\mathrm{r}=0,462$ dan $p<0,001)$ yang bermakna secara statistik antara kadar resistin serum dengan skor CTP. Ini berarti semakin tinggi skor CTP, maka akan semakin tinggi kadar resistin serum. Peningkatan kadar resistin serum ini tidak disebabkan oleh gangguan bersihan hepatik yang terganggu pada disfungsi hati berat, namun bisa diakibatkan oleh peningkatan produksi makrofag jaringan (sel Kupffer) sebagai respon terhadap inflamasi. Hal ini diperkuat dengan penelitian yang dilakukan oleh Bahr dkk. (2006) yang mendapatkan adanya kadar resistin serum pada vena hepatika yang lebih tinggi dibandingkan dengan arteri hepatika. ${ }^{15}$

Hasil ini sesuai dengan penelitian yang dilakukan oleh Yagmur dkk. yang menemukan adanya korelasi resistin dengan skor CTP pada pasien SH dengan $r=0,391, p=$ $0,001) \cdot{ }^{17}$ Meskipun penelitian ini sudah dilakukan pada pasien Kaukasia dengan etiologi SH yang lebih banyak disebabkan oleh non viral, hal tersebut tidak menjadi masalah karena yang ingin dilihat adalah respon hati dalam memproduksi resistin pada pasien Mongoloid dengan etiologi SH yang lebih banyak disebabkan oleh hepatitis virus, terutama virus hepatitis B dan C. Peningkatan resistin pada kasus gangguan hati dan komplikasinya akibat sindrom metabolik sudah banyak dijumpai dan sudah barang tentu kedua hal ini berhubungan terkait hubungannya dengan resistensi insulin, namun peningkatan protein ini pada kasus $\mathrm{SH}$ masih sedikit sekali diteliti dan mekanisme yang menyertainya. Hasil penelitian ini menunjukkan bahwa SH merupakan kondisi klinis yang kompleks yang bukan hanya ditandai oleh kegagalan hepatoselular dan hipertensi portal, namun juga berpengaruh pada gangguan metabolisme, yaitu dalam hal ini metabolisme glukosa yang ditunjukkan melalui peningkatan kadar resistin serum.

Perubahan metabolisme glukosa umum dijumpai pada pasien SH dan akan semakin berat seiring dengan perjalanan klinis penyakit hati. Sekitar 10-15\% pasien SH akan mengalami DM pada masa yang akan datang. Walaupun hiperinsulinemia sering dijumpai pada pasien SH, kerja insulin di otot umumnya tidak efektif. Pada berbagai kondisi resistensi insulin seperti obesitas dan DM tipe 2, resistin adalah protein yang dituduh menghambat kerja insulin di perifer. Dengan adanya penelitian ini yang menunjukkan adanya korelasi positif resistin dan skor CTP, bisa jadi resistin memegang peranan kunci pada resistensi insulin pasien $\mathrm{SH} .{ }^{3}$

Adanya korelasi bermakna antara resistin dan skor CTP pada penelitian ini sesuai dengan hasil dari penelitian sebelumnya yang menyatakan bahwa peningkatan resistin berhubungan dengan kondisi proinflamasi dan resistensi insulin pada $\mathrm{SH}^{16,17}$ Dan penelitian ini juga lebih spesifik pada populasi pasien Asia yang penyebab SHnya mayoritas disebabkan oleh virus.

Beberapa kondisi yang berpengaruh terhadap resistin antara lain adalah: usia, jenis kelamin, indeks massa tubuh, dan kadar CRP. Setelah dilakukan analisis multivariat, hanya dua variabel yang berkorelasi dengan resistin yaitu skor CTP dan CRP. Usia tidak berpengaruh terhadap kadar resistin. Menurut Nusken (2006), kadar resistin dipengaruhi oleh umur, dengan kadar yang lebih tinggi pada masa kanakkanak dan remaja dibandingkan anak umur pertengahan. ${ }^{23}$ Perbedaan ini dapat dijelaskan oleh adanya perbedaan usia pada subyek yang diteliti, yaitu sebagian besar pada kelompok usia yang lebih lanjut dengan rerata usia 53,21 tahun. Pada penelitian sebelumnya fluktuasi kadar resistin lebih banyak dijumpai pada usia yang lebih muda, yaitu pada populasi anak, sedangkan pada usia dewasa kelihatannya tidak ada pengaruh usia terhadap kadar resistin.

Analisis kadar resistin serum dengan jenis kelamin pada penelitian ini menunjukkan tidak ada perbedaan yang signifikan antara kadar resistin serum pria dibanding dengan wanita. Hasil ini konsisten dengan observasi yang dilakukan oleh Nieva-Vazquez dkk. (2014). ${ }^{24}$ Namun, penelitian lainnya melaporkan bahwa kadar resistin didapatkan lebih tinggi pada wanita dibandingkan dengan pria, suatu diskrepansi yang bisa saja disebabkan oleh fakta bahwa pada penelitian ini tidak diimbangi dengan distribusi jenis kelamin yang sama. ${ }^{25}$ Oleh karena itu, hal ini bisa saja terjadi karena jumlah subjek wanita yang lebih sedikit sehingga analisis yang dilakukan tidak memiliki cukup power untuk mendeteksi perbedaan kadar resistin berdasarkan jenis kelamin.

Resistin tidak menunjukkan adanya hubungan dengan IMT. Pada penelitian yang dilakukan oleh Azuma dkk. (2003), memang terdapat hubungan antara resistin dengan IMT. ${ }^{26}$ Namun hal ini masih kontroversial, mengingat resistin pada manusia sangat dipengaruhi oleh makrofag jaringan dan hanya sebagian kecil yang dipengaruhi oleh adiposit. Pada penelitian ini, kelihatannya tidak adanya hubungan resistin dengan IMT dapat dijelaskan dari sumber produksi resistin yang tidak ada hubungannya dengan jaringan adiposit pada pasien $\mathrm{SH}$.

Resistin berkorelasi positif dengan CRP. Hal ini menunjukkan bahwa peningkatan resistin yang didapat pada disfungsi hati berat kelihatannya dimediasi oleh inflamasi dan sesuai dengan hasil penelitian Bahr dkk. (2006) yang menyatakan adanya korelasi positif bermakna antara resistin dan CRP. ${ }^{15}$ Kondisi inflamasi akan merangsang sitokin untuk memacu hepatosit memproduksi CRP. Perubahan protein fase akut ini bisa terjadi pada kondisi noninfeksi, misalnya KHS, nekrosis atau reaksi inflamasi lokal pada SH dan translokasi bakterial yang berpotensi menginduksi sintesis protein fase akut ini. ${ }^{27}$ Peningkatan CRP serum inilah yang akan meningkatkan ekspresi gen resistin pada disfungsi hati berat. 
Dengan analisis regresi linier multipel diketahui bahwa hanya 20,6\% konsentrasi resistin serum ditentukan oleh skor CTP dan CRP dengan persamaan resistin $=(0,271 \times \mathrm{CRP})$ + (2,684 x skor CTP) - 5,385, sedangkan 79,4\% ditentukan oleh faktor-faktor lain. Dari nilai kemaknaannya, ternyata hubungan resistin dengan skor CTP maupun dengan CRP pada penelitian ini bermakna secara statistik $(\mathrm{p}=0,001$ dan 0,027 ) walaupun telah dianalisis secara multivariat. Ini berarti bahwa skor CTP maupun CRP merupakan penentu utama (true independent variable) konsentrasi resistin serum.

Penelitian ini menunjukkan hubungan yang sukar dipisahkan antara resistin dengan skor CTP. Peningkatan resistin pada populasi SH bisa dijelaskan secara direk maupun indirek. Secara direk, SH yang tidak dapat dipisahkan dari adanya kondisi inflamasi noninfeksi akan memicu makrofag jaringan seperti sel Kupffer untuk menghasilkan resistin. Kondisi inflamasi sendiri juga akan meningkatkan resistin secara indirek melalui peningkatan sitokin proinflamasi seperti CRP dan TNF- $\alpha$ yang dihasilkan oleh hepatosit. Keadaan ini juga dibuktikan pada penelitian ini melalui analisis bivariat yang dilanjutkan dengan analisis multivariat yang menunjukkan adanya hubungan antara skor CTP dan kadar CRP serum dengan kadar resistin. Hal-hal inilah yang berperan dalam meningkatkan resistin dalam sirkulasi.

Resistin sendiri akan berikatan dengan reseptor TLR-4 di jaringan dan meningkatkan ekspresi SOCS-3 dan PTP-1B yang merupakan regulator negatif signaling insulin. Peningkatan ekspresi regulator negatif ini akan mengakibatkan penghambatan terhadap kerja insulin di jaringan. Hal inilah yang kemungkinan mendasari terjadinya resistensi insulin pada pasien $\mathrm{SH}^{28}$

Dengan menggunakan analisis statistik, ternyata diketahui bahwa kontribusi faktor-faktor yang diperiksa dalam penelitian ini hanya berdampak sedikit pada peningkatan kadar resistin pasien SH. Keluasan dari spektrum penyakit SH ini bisa terlihat pada penelitian ini. SH bukan merupakan penyakit yang sederhana yang ditangani sebatas pada proses kegagalan hepatoselular dan hipertensi portal saja, namun lebih jauh dari itu. Gangguan pada proses metabolisme, yaitu dalam hal ini metabolisme glukosa, yang ditandai dengan adanya peningkatan kadar resistin juga telah dibuktikan pada penelitian ini dan beberapa penelitian lain. Selain itu produksi resistin oleh makrofag jaringan juga meninggalkan tanda tanya besar. Pada kondisi SH yang secara definisi sudah terjadi fibrosis yang difus, berapa banyak sel Kupffer yang masih tersisa dalam proses produksi resistin. Selain itu, apakah benar memang resistin masih dapat merupakan target terapi untuk mencegah fibrosis lebih lanjut pada hati yang sudah mengalami sirosis. Pertanyaan-pertanyaan ini akan dapat dijawab seiring dengan semakin majunya penelitian biomolekular dalam menilai mekanisme fibrosis pada SH itu sendiri. Kondisi kronis ini kelihatannya masih perlu didalami dengan lebih jauh lagi. Namun, setidaknya penelitian ini dapat dijadikan dasar berpijak untuk penelitian berikutnya dalam mendalami kondisi inflamasi dan resistensi insulin pada pasien SH dan dapat membantu perkembangan diagnostik dan terapi menyeluruh.

Penelitian ini bukan tanpa keterbatasan. Beberapa keterbatasan antara lain tidak melakukan pengambilan sitokin proinflamasi lain dan insulin sebagai bagian dari pengukuran terhadap resistensi insulin. Akibatnya peningkatan resistin sesuai dengan derajat beratnya penyakit sirosis hati pada penelitian ini masih dipertanyakan apakah memang disebabkan oleh inflamasi dan resistensi insulin atau ada penyebab lain. Selain itu faktor yang dapat mempengaruhi kadar resistin serum yaitu beratnya hipertensi porta tidak diperiksa pada penelitian ini karena keterbatasan biaya.

\section{DAFTAR PUSTAKA}

1. Bacon, B.R. 2012. Cirrhosis and Its Complications. In : Longo, D.L., Fauci, A.S., Kasper, D.L., Hauser, S.L., Jameson, J.L., Loscalzo, J. (eds). Harrison's Principles of Internal Medicine. $18^{\text {th }}$ ed. New York: McGraw-Hill; 2012: 2592-602.

2. Nurdjanah, S. Sirosis Hati. Dalam : Sudoyo, A.W., Setiyohadi, B., Alwi, I., Simadibrata, M., Setiati, S. (eds). Buku Ajar Ilmu Penyakit Dalam. Edisi V. Jakarta: Interna Publishing; 2009: 668-73.

3. Tietge, U.J.F., Selberg, O., Kreter, A., Bahr, M.J., Pirlich, M., Burchert, W., Müller, M.J., Manns, M.P., Böker, K.H.W. Alterations in Glucose Metabolism Associated With Liver Cirrhosis Persist in the Clinically Stable Long-Term Course After Liver Transplantation. Liver Transpl; 2004: 10:1030-40.

4. Falasca, K., Ucciferri, C., Dalessandro, M., Zingariello, P., Mancino, P., Petrarca, C., Pizzigallo, E., Conti, P., Vecchiet, J. Cytokine Patterns Correlate with Liver Damage in Patients with Chronic Hepatitis B and C. Annals of Clinical \& Laboratory Science; 2006: 36(2):144-50.

5. Petrides, A.S., Groop, L.C., Riely, C.A., DeFronzo, R.A. Effect of Physiologic Hyperinsulinemia on Glucose and Lipid Metabolism in Liver Cirrhosis. J Clin Invest; 1991: 88(2):561-70

6. Compean, D.G., Quintana, J.A.G., Gonzales, J.A.G., Garza, H.M. Liver Cirrhosis and Diabetes: Risk Factors, Pathophysiology, Clinical Implications and Management. World J Gastroenterol; 2009: 15(3):280-88.

7. Mutsaers, S.E., Bishop, J.E., McGrouther, G., Laurent, G.J. 1997. Mechanisms of Tissue Repair: from Wound Healing to Fibrosis. Int J Biochem Cell Biol; 1997: 29(1):517. 
8. Asano, H., Izawa, H., Nagata, K., Nakatochi, M., Kobayashi, M., Hirashiki, A., Shintani, S., Nishizawa, T., Tanimura, D., Naruse, K., Matsubara, T., Murohara, T., Yokota, M. 2010. Plasma Resistin Concentration Determined by Common Variants in The Resistin Gene and Associated with Metabolic Traits in Aged Japanese Population. Diabetologia; 2010: 53:234-46.

9. Fantuzzi, G. Adipose Tissue, Adipokines, and Inflammation. J Allergy Clin Immunol; 2005: 115(5):91119.

10. Ronti, T., Lupatelli, G., Mannarino, E. The Endocrine Function of Adipose Tissue: An Update. Clinical Endocrinology; 2006: 64:355-65.

11. Holcomb, I.N., Kabakoff, R.C., Chan, B., Baker, T.W., Gurney, A., Henzel, W., Nelson, C., Lowman, H.B., Wright, B.D., Skelton, N.J., Frantz, G.D., Tumas, D.B., Peale, F.V., Shelton, D.L., Hébert, C.C. FIZZ1, A Novel Cysteine-Rich Secreted Protein Associated with Pulmonary Inflammation, Defines A New Gene Family. The EMBO Journal; 2001: 19(15):4046-55.

12. Steppan, C.M., Lazar, M.A. The Current Biology of Resistin. Journal of Internal Medicine; 2004: 255:439-47.

13. Kershaw, E.E., Flier, J.S. Adipose Tissue as An Endocrine Organ. J Clin Endocrinol Metab; 2004:89:2548-56.

14. Bertolani, C., Marra, F. The Role of Adipokines in Liver Fibrosis. Pathophysiology; 2008: 15(2):91-101.

15. Bahr, M.J., Ockenga, J., Böker, K.H.W., Manns, M.P., Tietge, U.J.F. Elevated Resistin Levels in Cirrhosis are Associated with the Proinflammatory State and Altered Hepatic Glucose Metabolism but Not with Insulin Resistance. Am J Physiol Endocrinol Metab; 2006: 291:199206.

16. Kakizaki, S., Sohara, N., Yamazaki, Y., Horiguchi, N., Kanda, D., Kabeya, K., Katakai, K., Sato, K., Takagi, H., Mori, M. Elevated Plasma Resistin Concentrations in Patients with Liver Cirrhosis. Journal of Gastroenterology and Hepatology; 2008: 23:73-77.

17. Yagmur, E., Trautwein, C., Gressner, A.M., Tacke, F. Resistin Serum Levels Are Associated with Insulin Resistance, Disease Severity, Clinical Complications, and Prognosis in Patients with Chronic Liver Diseases. Am J Gastroenterol; 2006: 101:1244-52.

18. Tsiakalos, A., Karatzaferis, A., Ziakas, P., Hatzis, G. Acute phase proteins as indicators of bacterial infections in patients with cirrhosis. Liver Int; 2009: 29(10):1538-42.
19. Kenny-Walsh, E. Clinical Outcomes after Hepatitis C Infection from Contaminated Anti-D Immune Globulin. Irish Hepatology Research Group. N Engl J Med; 1999: 340(16):1228-33.

20. Somia A.I.K., Suryadarma I.G.A., Purwadi N., Wibawa I.D.N. Gastropati Hipertensi Portal: Penelitian Retrospektif pada Pasien Sirosis Hati di RS Sanglah Denpasar. Majalah Penyakit Dalam Udayana Denpasar; 2004: 5:18-22.

21. Ndraha, S., Wician, F., Tendean, M., Sunardi, I.D.P., Santoso, M. Impaired Glucose Metabolism in Liver Cirrhosis. Indones J Gastroenterol Hepatol Dig Endosc; 2013: 14(2):85-9.

22. Heidelbaugh, J.J., Bruderly, M. Cirrhosis and Chronic Liver Failure: Part I. Diagnosis and Evaluation. Am Fam Physician; 2006: 74(5):756-62.

23. Nüsken, KD, Kratzsch, J, Wienholz, V, Stöhr, W, Rascher, W. Circulating Resistin Concentrations in Children Depend on Renal Function. Nephrol Dial Transplant; 2006: 21:107-12.

24. Nieva-Vazquez, A., Perez-Fuentes, R., Torres-Rasgado, E., Lopez-Lopez, J.G., Romero, J.R. Serum Resistin Levels are Associated with Adiposity and Insulin Sensitivity in Obese Hispanic Subjects. Metab Syndr Relat Disord: 2014: 12(2):143-48

25. Norata GD, Ongari M, Garlaschelli K, Raselli S, Grigore L. 2007. Plasma Resistin Levels Correlate with Determinants of The Metabolic Syndrome. European J of Endocrinol; 2007: 156(2):279-84.

26. Azuma, K., Katsukawa, F., Oguchi, S., Murata, M., Hajime, Y., Shimada, A., Saruta, T. Correlation Between Serum Resistin Level and Adiposity in Obese Individuals. Obes Res; 2003: 11:997-1001.

27. Gonzales, J.A.G., Sierra, C.M., Ramos, C.R. Implication of Inflammation-Related Cytokines in the Natural History of Liver Cirrhosis. Liver International; 2004: 24:437-45.

28. Benomar Y, Amine H, Crepin D, Al Rifai S, Riffault L, Gertier A, et al. Central Resistin/ TLR4 Impairs Adiponectin Signaling, Contributing to Insulin and FGF21 Resistance. Diabetes, 2016; 65(4):913-26.

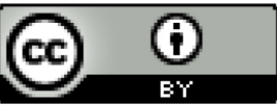

This work is licensed under a Creative Commons Attribution 4.0 International License. 